\title{
ANALISIS SDM GUNA MENINGKATKAN KINERJA KARYAWAN DENGAN METODE SWOT DAN QUANTITATIVE STRATEGIC PLANNING MATRIX (QSPM) DI PT. INDO SADANG FABRIKATOR
}

\author{
${ }^{1}$.Agung Widarman, M.T., ${ }^{2 .}$ Rohim, ST, ${ }^{3}$ Haris Sandi Yudha, M.T. \\ Teknik Industri, STT Wastukancana Purwakarta \\ 1.agung@stt-wastukancana.ac.id, 2. tirohim33@gmail.com, 3. sandi@stt-wastukancana.ac.id
}

\begin{abstract}
Abstrak
Tujuan penelitian ini yaitu untuk mengetahui strategi untuk meningkatkan kinerja karyawan, untuk mengetahui hasil analisis SWOT terhadap strategi peningkatan kinerja karyawan dan untuk mengetahui hasil analisis QSPM terhadap strategi peningkatan kinerja karyawan. Alat analisis yang digunakan dalam menganalisis penelitian ini adalak matriks IFE, matriks EFE, matriks IE, Analisis SWOT dan QSPM. Setelah mengetahui kondisi internal dan eksternal perusahaan, maka dapat diperoleh hasil matriks IFE dan EFE melalui kuesioner yang telah disebarkan kepada responden yang sudah dipilih. Matriks IFE menghasilkan total skor 3,529 dan matriks EFE menghasilkan total skor sebesar 3,185. Mengacu pada hasil matriks IFE dan EFE, maka disusunlah matriks IE untuk menentukan posisi perusahaan, maka posisi perusahaan saat ini berada di kuadran I (grow and built). Berdasarkan analisis matriks SWOT dan matriks IE, dihasilkan 3 alternative yaitu Program peningkatan kompetensi karyawan, Program pelatihan leader dan karyawan untuk posisi strategis, dan Membangun kedisplinan dengan punishment and reward yang ketat. Hasil dari perhitungan menggunakan analisis matriks QSPM didapatkan alternatif strategi utama yang memiliki nilai TAS tertinggi yaitu Program peningkatan kompetensi karyawan dengan nilai TAS 6,248.
\end{abstract}

\section{Kata Kunci: SDM, Kinerja Karyawan, Matrik IFE dan EFE, Matrik IE, Analisa SWOT dan QSPM}

\section{Pendahuluan}

Kinerja juga merupakan hasil kerja yang dihasilkan atau disumbangkan seorang karyawan yang berkaitan dengan tugas dan tanggung jawab kepada perusahaan. Kinerja yang tinggi dapat dibentuk dengan adanya kesadaran setiap pemimpin perusahaan untuk memberikan dukungan kepada pegawai berupa keikutsertaan pemimpin dalam memberikan arahan mengenai pekerjaan yang dilakukan oleh setiap pegawai. Seorang karyawan yang termotivasi akan bersifat energik dan bersemangat, dan sebaliknya seorang karyawan dengan motivasi yang rendah akan sering menampilkan rasa tidak nyaman dan tidak senang terhadap pekerjaannya yang mengakibatkan kinerja mereka menjadi buruk dan tujuan perusahaan tidak akan tercapai.

Banyak cara yang dapat dilakukan oleh sebuah perusahaan untuk meningkatkan mutu sumber daya manusia sehingga menjadi tenaga kerja yang berkualitas, diantaranya dengan mengadakan pengembangan diri, motivasi terhadap karyawan atau dengan pemberian kompensasi yang sesuai dengan apa yang diharapkan oleh tenaga kerja serta kesesuaian imbalan dengan apa yang telah disepakati oleh karyawan dan pihak perusahaan.

Di PT Indo Sadang Fabrikator tingkat disiplin kerja karyawan dirasa masih kurang hal ini terlihat masih ditemui kasus pegawai tidak hadir untuk bekerja, pegawai yang terlambat datang juga akan mengakibatkan tidak efektifnya waktu yang digunakan untuk menyelesaikan tugas pekerjaannya. Berdasarkan uraian di atas, maka peneliti tertarik untuk untuk membahas permasalahan tersebut sebagai bahan penelitian.

\section{Kajian Pustaka}

2.1 Manajemen Sumber Daya Manusia

Manajemen sumber daya manusia dalam sebuah bisnis didefinisikan sebagai menejemen pencairan, pemilihan, pendayagunaan, pengembangan, dan pemeliharaan sumber daya organisasi yang terpenting yaitu manusia. Manajemen sumber daya manusia dapat juga disebut sebagai kegiatan perencanaan, pengorganisasian, pengarahan dan pengedalian atas pengadaan konsep dan tantangan menajemen sumber daya manusia tenaga kerja, pengembangan, konpensasi, integrasi, pemeliharaan dan pemutusan hubungan kerja dengan sumber daya manusia untuk mencapai sasaran perorangan, organisasi dan masyarakat.

\subsection{Kinerja karyawan}

Kinerja adalah hasil kerja yang dapat dicapai oleh seseorang atau sekelompok orang dalam suatu organisasi, sesuai dengan wewenang dan tanggung jawab masing-masing dalam rangka upaya mencapai tujuan organisasi bersangkutan secara legal, tidak melanggar hukum, dan sesuai dengan moral maupun etika. Kinerja juga dapat diartikan sebagai kualitas, kuantitas dan waktu yang digunakan sejauh mana menjalankan tugas. Kuantitas adalah hasil yang diperhitungkan sejauh mana seseorang dapat berhasil mencapai tujuan yang telah ditetapkan, kualitas adalah bagaimana seseorang menjalankan tugasnya.

\subsection{Analisis Internal Factor Evaluation (IFE)}

Menurut Rangkuti (2006), matriks IFE digunakan untuk mengetahui faktor-faktor internal perusahaan yang berkaitan dengan kekuatan dan kelemahan yang dianggap penting. Data internal perusahaan dapat diambil informasi dari beberapa 
fungsional perusahaan, misalnya dari aspek sumber daya manusia, pemasaran, produksi, keuangan, sistem informasi dan organisasi.

\subsection{Analisis External Factor Evaluation \\ (EFE)}

Menurut Rangkuti (2006) matriks EFE digunakan untuk mengevaluasi faktor-faktor eksternal perusahaan. Faktor eksternal yang dikumpulkan menyangkut persoalan ekonomi, social, lingkungan, politik, teknologi dan ekologi. Masalah tersebut penting karena faktor eksternal perusahaan berpengaruh secara langsung maupun tidak langsung terhadap kinerja perusahaan.

\subsection{Analisis Matriks Internal-Eksternal (IE)}

Analisis IE merupakan analisis penggabungan dari factor internal dan eksternal. Parameter yang digunakan meliputi parameter kekuatan internal perusahaan dan pengaruh eksternal yang dihadapi. Tujuan penggunaan model ini adalah memperoleh strategi bisnis di tingkat korporat yang lebih detail (Rangkuti 2006).

\subsection{Analisis SWOT}

Menurut Freddy Rangkuti Analis swot adalah indifikasi berbagai factor secara sistematis untuk merumuskan strategi perusahan. Analisis ini didasarkan pada logika yang dapat memaksimalkan kekuatan (sterngths) dan peluang (opportunities), namun secara bersamaan dapat meminimalkan kelemahan (weaknesses) dan ancaman (threats).

\subsection{Quantitativ Strategic Planning Matrix (QSPM)}

Menurut Umar (2003, dikutip oleh Usman, 2013), QSPM adalah alat yang direkomendasikan bagi para ahli strategi untuk melakukan evaluasi pilihan strategi alternaif secara obyektif, berdasarkan key success factors internal-ekstenal yang telah diidentifikasikan sebelumnya.

\section{Analisa dan Pembahasan}

\subsection{Analisis Internal Factor Evaluation (IFE)}

Analisis lingkungan internal dilakukan dengan meninjau faktor- faktor dalam perusahaan yang menjadi kekuatan dan kelemahan bagi perusahaan.

Tabel 3.1 Analisis IFE

\begin{tabular}{|c|c|c|c|c|}
\hline No & Faktor Internal & Bobot & Rating & Skor \\
\hline & Kekuatan & & & \\
\hline 1 & Memiliki pimpinan yang care terhadap Karyawan & 0,287 & 4 & 1,148 \\
\hline 2 & Keharmonisan Karyawan & 0,179 & 3,75 & 0,671 \\
\hline 3 & Kenyamanan di Lingkungan kerja & 0,198 & 3,5 & 0,693 \\
\hline & Kelemahan & 0,664 & & 2,512 \\
\hline & Kurangnya disiplin waktu pada karyawan & 0,132 & 3,25 & 0,429 \\
\hline 1 & Jenjang karir yang kurang jelas & 0,105 & 3 & 0,315 \\
\hline 2 & Tingkat kopetensi karyawan yang kurang & 0,099 & 2,75 & 0,272 \\
\hline 3 & & 0,336 & & 1,016 \\
\hline & Total & 1,00 & & 3,529 \\
\hline & \multicolumn{3}{|c}{} \\
\hline
\end{tabular}

3.2 Analisis External Factor Evaluation (EFE)
Lingkungan eksternal meliputi faktor-faktor di luar perusahaan yang dapat menimbulkan peluang dan ancaman bagi perusahaan. Tujuan dari audit eksternal adalah untuk mengembangkan daftar terbatas peluang yang dapat dimanfaatkan oleh perusahaan dan ancaman yang harus dihindari.

Tabel 3.2 Analisis EFE

\begin{tabular}{|c|c|c|c|c|}
\hline No & Faktor Ekstemal & Bobot & Rating & Skor \\
\hline & Peluang & & & \\
\hline 1 & $\begin{array}{l}\text { Banyak dinas lapangan yang mampu meningkatkan } \\
\text { keriasama dan kemampuan leadership }\end{array}$ & 0,298 & 4 & 1,192 \\
\hline 2 & Banyak bekerjasama dengan berbagai instansi & 0,262 & 3 & 0,786 \\
\hline & & 0,560 & & 1,978 \\
\hline & Ancaman & & & \\
\hline 1 & Cara kerja yang masih manual & 0,226 & 2,5 & 0,565 \\
\hline 2 & Posisi strategis di perusahaan yang mash ditempati TKA & 0,214 & 3 & 0,642 \\
\hline & & 0,440 & & 1,207 \\
\hline & Total & 1,00 & & 3,185 \\
\hline
\end{tabular}

\subsection{Analisis Matriks Internal Eksternal (IE)}

Analisis Matriks Internal Eksternal merupakan matriks portofolio yang menempatkan berbagai divisi dalam suatu organisasi dalam diagram yang sistematis. Matriks ini menggabungkan informasi yang didapatkan dari matriks IFE dan EFE tentang posisi atau kekuatan perusahaan berdasarkan kondisi internal dan eksternal organisasi. Mengacu pada hasil matriks IFE dan EFE, maka disusunlah matriks IE yang berdasarkan hasil penjumlahan total skor bobot pada matriks IFE sebesar 3,529 dan EFE sebesar 3,185.

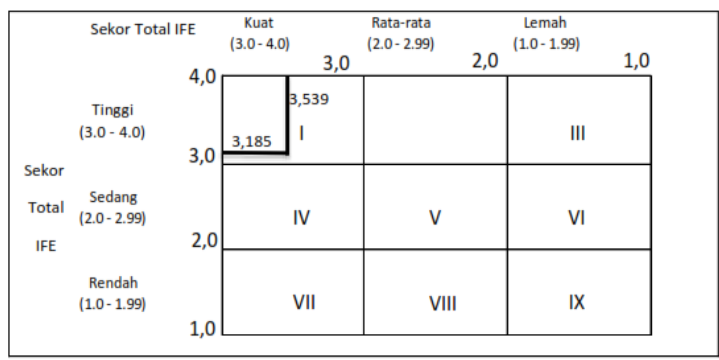

Gambar 3.1 Matrik IE

\subsection{Analisis SWOT}

Berdasakan hasil identifikasi dengan menggunakan matriks IFE dan EFE yang menggambarkan kekuatan dan kelemahan yang dimiliki perusahaan serta peluang dan ancaman yang dihadapi perusahaan dengan menggunakan matriks SWOT (Strenght, Weakness, Opportunities, and Threats) dapat diperoleh alternative strategi dengan mengkombinasikan faktor-faktor internal dan eksternal perusahaan. Matriks SWOT menghasilkan empat tipe strategi yaitu strategi SO (Strenght-Opportunities), strategi WO (Weakness-Opportunities), strategi ST (Strenght-Threats), strategi WT (WeaknessThreats). 
Tabel 3.3 Tabel Analisis SWOT

\begin{tabular}{|c|c|c|}
\hline Eksternal & $\begin{array}{l}\text { STRENGTH (S) } \\
\text { 1.Memiliki pimpinan yang } \\
\text { care terhadap Karyawan } \\
\text { 2.Kehamonisan Karyawan } \\
\text { 3.Kenyamanan di Lingkungan } \\
\text { Kerja }\end{array}$ & $\begin{array}{l}\text { WEAKNESSES (W) } \\
\text { 1.Kurangnya disiplin waktu } \\
\text { pada karyawan } \\
\text { 2.Jenjang karir yang kurang } \\
\text { jelas } \\
\text { 3.Tingkat kopetensi karyawan } \\
\text { yang kurang }\end{array}$ \\
\hline $\begin{array}{l}\text { OPPERTUNITIES(O) } \\
\text { 1.Banyak dinas lapangan yang } \\
\text { mampu meningkatkan kerjasama } \\
\text { dan kemampuan leadership } \\
\text { 2.Banyak bekerjasama dengan } \\
\text { berbagai instansi }\end{array}$ & $\begin{array}{l}\text { STRATEGI SO } \\
\text { aMeningkatkan kepemimpinan } \\
\text { yang care atau perduli pada } \\
\text { kepada karyawan secara } \\
\text { merata disemua departemen. } \\
\text { b.Meningkatkan tingkat } \\
\text { keharmonisan antar karyawan } \\
\text { secara berkesinambungan } \\
\text { c. Rutin mengikutsertakan } \\
\text { leader dan atau operator untuk } \\
\text { bertugas dan bertanggung } \\
\text { jawab di lapangan } \\
\text { d.Terus berusaha } \\
\text { meningkatkan kerjasama yang } \\
\text { baik dan berkesinambungan } \\
\text { dengan berbagai instansi. }\end{array}$ & 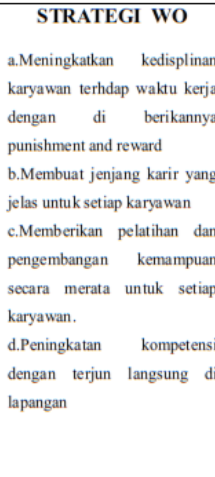 \\
\hline $\begin{array}{l}\text { THREATS (T) } \\
\text { 1.Cara kerja yang masih manual } \\
\text { 2.Posisi strategis di perusahaan } \\
\text { yang masih ditempati TKA }\end{array}$ & $\begin{array}{l}\text { STRATEGI ST } \\
\text { a.Otomatisasi sederhana pada } \\
\text { pekerjaan-pekerjaan manual } \\
\text { b.Peningkatan kepemimpinan } \\
\text { yang baik untuk semua } \\
\text { karyawan dan semua } \\
\text { departemen. } \\
\text { c.Mempersiapkan program } \\
\text { management trainee unuk } \\
\text { mencari potensi pada } \\
\text { karyawan untuk menempati } \\
\text { pososi strategis }\end{array}$ & $\begin{array}{l}\text { STRATEGI WT } \\
\text { a.Menciptakan aturan yang } \\
\text { baku terhadap kedisplinan } \\
\text { waktu kerja, memberikan } \\
\text { pelatihan dan jengiang kariu } \\
\text { yang samabagisetiap karyawan } \\
\text { sesuai kebutuhan perusahaan. } \\
\text { b.menyiapkan karyawan } \\
\text { internal yang memiliki potensi } \\
\text { untuk menjadi leader. }\end{array}$ \\
\hline
\end{tabular}

\subsection{Analisis Matriks QSPM}

Berdasarkan analisis matriks SWOT dan matriks IE, dihasilkan beberapa alternative strategi pemasaran. Stategi yang dihasilkan akan disusun ke dalam matriks QSPM.

Tabel 3.4 Matrik QSPM

\begin{tabular}{|c|c|c|c|c|c|c|c|c|}
\hline \multirow{3}{*}{ No } & \multirow{3}{*}{ Faktor Intemal-Ekste mal } & \multirow{3}{*}{$\begin{array}{c}\text { Nilai } \\
\text { Bobot }\end{array}$} & \multicolumn{6}{|c|}{ Altemative Strategi } \\
\hline & & & \multicolumn{2}{|c|}{$\begin{array}{l}\text { Progam peningkatan } \\
\text { konpetersi karyaran }\end{array}$} & \multicolumn{2}{|c|}{\begin{tabular}{|c|}
$\begin{array}{c}\text { Propram pelatilan leader } \\
\text { dan karyawan untuk } \\
\text { posisi strategis }\end{array}$ \\
\end{tabular}} & \multicolumn{2}{|c|}{$\begin{array}{l}\text { Membangan kedisplinan } \\
\text { dengan purisment and } \\
\text { rewrard yang ketat }\end{array}$} \\
\hline & & & AS & TAS & AS & TAS & AS & TAS \\
\hline & Strength/Kekuatan & & & & & & & \\
\hline 1 t & $\begin{array}{l}\text { Menilki pimpinan yang care } \\
\text { terhadap Karyawan }\end{array}$ & 0,287 & 3,750 & 1,076 & 3,000 & 0,861 & 3,750 & 1,076 \\
\hline $2 \mathrm{I}$ & Kehamorisan Karyawan & 0,179 & 3,500 & 0,627 & 2,500 & 0,448 & 3,000 & 0,537 \\
\hline & $\begin{array}{l}\text { Kenyamanan di Lingkngan } \\
\text { Kerja }\end{array}$ & 0,198 & 3,000 & 0,594 & 2,750 & 0,545 & 2,750 & 0,545 \\
\hline & \begin{tabular}{|l|l} 
Neakness/Kele ma han \\
\end{tabular} & & & & & & & \\
\hline 1 & $\begin{array}{l}\text { Kurangysa disiplin waktu } \\
\text { pada karyawan }\end{array}$ & 0,132 & 3,250 & 0,429 & 3,250 & 0,429 & 2,750 & 0,363 \\
\hline 2 & $\begin{array}{l}\text { Jeriang kari yang kurang } \\
\text { ielas }\end{array}$ & 0,105 & 2,750 & 0,289 & 2,000 & 0,210 & 2,500 & 0,263 \\
\hline 3 & \begin{tabular}{|l|} 
Tinglat kopetensi karyawan \\
tang kurang
\end{tabular} & 0,099 & 2,500 & 0,248 & 2,250 & 0,223 & 2,250 & 0,223 \\
\hline t & Opper & & & & & & & \\
\hline & 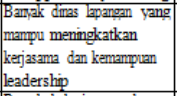 & 0,298 & 3,500 & 1,043 & 3,250 & 0,969 & 3,000 & 0,894 \\
\hline 2 & \begin{tabular}{|l|} 
Bayjakl bekejajama dergann \\
berbagai instansi
\end{tabular} & 0,262 & 3,000 & 0,786 & 2,750 & 0,721 & 2,750 & 0,721 \\
\hline & & & & & & & & \\
\hline 1 & $\begin{array}{l}\text { Cara kejaja yang masth } \\
\text { mamual }\end{array}$ & 0,226 & 2,750 & 0,622 & 2,250 & 0,509 & 2,750 & 0,622 \\
\hline 2 & \begin{tabular}{|l|} 
Posisi strategjis di pensahazan \\
kang masih ditennati TKA \\
\end{tabular} & 0,214 & 2,500 & 0,535 & 2,750 & 0,589 & 2,750 & 0,589 \\
\hline & & & & 6,248 & & 5,501 & & 5,831 \\
\hline
\end{tabular}

Berdasarkan hasil dari perhitungan menggunakan analisis matriks QSPM didapatkan alternatif strategi utama yang memiliki nilai TAS tertinggi yaitu Strategi program peningkatan kompetensi karyawan dengan nilai TAS 6,248. Strategi ini dilakukan dengan usaha-usaha rutin mengikutsertakan leader dan atau operator untuk bertugas dan bertanggung jawab di lapangan, otomatisasi sederhana pada pekerjaan-pekerjaan manual, menciptakan aturan yang baku terhadap kedisplinan waktu kerja, memberikan pelatihan dan jengjang karir yang sama bagi setiap karyawan sesuai kebutuhan perusahaan, terus berusaha meningkatkan kerjasama yang baik dan berkesinambungan dengan berbagai instansi, peningkatan kepemimpinan yang baik untuk semua karyawan dan semua departemen.

Strategi dengan prioritas kedua yaitu strategi membangun kedisplinan dengan punishment and reward yang ketat dengan nilai TAS 5,831, yaitu dilakukan denga usaha eningkatkan kedisplinan karyawan terhdap waktu kerja dengan di berikannya punishment and reward yang ketat dan mengikat. Strategi dengan prioritas ketiga yaitu Strategi program pelatihan leader dan karyawan untuk posisi strategis dengan nilai TAS 5,501, yaitu Dilakukan dengan mempersiapkan program management trainee unuk mencari potensi pada karyawan untuk menempati pososi strategis, menyiapkan karyawan internal yang memiliki potensi untuk menjadi leader.

\section{Kesimpulan}

Berdasarkan hasil dan analisis dari penelitian yang telah dilakukan maka penulis dapat mengambil kesimpulan bahwa

1. PT. Indo Sadang Fabrikator telah melakukan beberapa strategi dalam peningkatan kinerja karyawan,adapun strategi yang dilakukan sebagai berikut; strategi rektutmen PT Indo Sadang Fabrikator sesuai kebutuhan perusahaan dan dilakukan secara terbuka melalui websiste dan sesuai dengan kualifikasi yang telah ditentukan, penempatan posisi kerja karyawan manajemen sumber daya manusia mempertimbangkan keahlian,keterampilan dan skil yang dimiliki oleh karyawan, jenjang karir yang disesuaikan dengan kebutuhan dan disesuaikan dengan kompetensi karyawan, pengembangan sumber daya manusia dialkukan dengan pendidikan, pelatihan dan workshop, sistem manajemen penilaian kinerja karyawan masih dilakukan secara manual, dan penilaian dilakukan secara objektif untuk setiap karyawan yang dilakukan oleh HRGA.

2. Hasil anlisis SWOT PT Indo Sadang Fabrikator dalam peningkatan kinerja karyawan sangat baik, karena mengacu pada hasil matriks IFE dan EFE, maka disusunlah matriks IE yang berdasarkan hasil penjumlahan total skor bobot pada matriks IFE sebesar 3,529 dan EFE sebesar 3,185 . Skor bobot tersebut merupakan input bagi analisis matriks IE yang di petakan pada matriks IE, sehingga dapat diketahui posisi perusahaan, maka posisi perusahaan saat ini berada di kuadran I, yaitu suatu keadaan dimana perusahaan berada pada grow and build atau tumbuh dan membangun. 
Perusahaan berada pada posisi internal yang kuat dan merespon dengan baik peluang dan ancaman yang ada. perusahaan terus berusaha untuk meningkatkan efisiensi disegala bidang dalam rangka meningkatkan kinerja dan keuntungan.

3. Berdasarkan analisis matriks QSPM yang memetakan 3 alternatif strategi maka strategi yaitu program peningkatan kompetensi karyawan, program pelatihan leader dan karyawan untuk posisi strategis, membangun kedisplinan dengan punishment and reward yang ketat, yang terpilih yaitu program peningkatan kompetensi karyawan adalah mengikutsertakan leader dan atau operator untuk bertugas dan bertanggung jawab di lapangan, otomatisasi sederhana pada pekerjaan-pekerjaan manual, menciptakan aturan yang baku terhadap kedisplinan waktu kerja, memberikan pelatihan dan jengjang karir yang sama bagi setiap karyawan sesuai kebutuhan perusahaan, terus berusaha meningkatkan kerjasama yang baik dan berkesinambungan dengan berbagai instansi, peningkatan kepemimpinan yang baik untuk semua karyawan dan semua departemen yang memiliki total skor tertinggi sebesar 6,248.

\section{Saran}

Berdasarkan penelitian yang telah
dilakukan, maka penulis mengemukakan beberapa saran sebagai berikut:

1. Bagi Perusahaan

Dari hasil penelitian yang sudah dilakukan dapat digunakan sebagai referensi untuk PT Indo Sadang Fabrikator dalam hal pengelolaan SDM dan meningkatkan kinerja karywan dengan cara program peningkatan kopetensi kartawan.

\section{Bagi Keilmuan}

Hasil penelitian ini bisa dijadikan referensi dala hal serupa dala penelitian mengenai analisis SDM dan peningkatan kinera karyawan dan dapat menabah wawasan bagi pebaca

4. Untuk Penelitian

Untuk peneliti selanjutnya diharapkan agar dapat memaksimalkan kekurangan yang ada pada penenlitian sebelumnya, sehingga hasil penelitian lebih maksimal.

\section{DAFTAR PUSTAKA}

Ahmad Fajar, Arti Yusdiartila, Apendi Arsyad. (2017). Strategi Pemasaran Benih Cabai Besar (Capsiccum Annum L) Di Cv. Tani Mandiri Desa Ciherang Pondok Kecamatan Caringin Kabupaten Bogor

Akhmadi, Hermanto Siregar, dan M Parulian Hutagaol. (2015). Pengembangan
Agribisnis Sebagai Strategi

Penanggulangan Kemiskinan Di Perdesaan

Anik Juniastuti, A Faroby Falatehan, Pudji Muljono. (2018). Strategi Peningkatan Kualitas Konten Diklat Berbasis ELearning Pada Pusdiklat Anggaran Dan Perbendaharaan.

Aris Nugroho, Siti Nandiroh, Etika Muslimah. (2016). Analisis Strategi Pemasaran Dengan Menggunakan Metode Quantitative Strategic Planning Matrix (Qspm) Pada Usaha Mebel

Desy Erika Permatasari, Djamhur Hamid, Wilopo. (2017). Penentuan Strategi Bisnis Manajemen Hotel Dalam Menghadapi Persaingan (Studi Kasus Di Quds Royal Hotel Surabaya)

Hany Setyorini, Mas'ud Effendi, Imam Santoso. (2016). Analisis Strategi Pemasaran Menggunakan Matriks SWOT Dan QSPM (Studi Kasus: Restoran WS Soekarno Hatta Malang)

Nizar Sapta Nuary. (2016). Strategi Pemasaran Dengan Pendekatan Analisis SWOT pada PT. Super Sukses Motor Banjarmasin

Nyimas Ekinevita Putri, Retno Astuti, Shyntia Atica Putri. (2019). Perencanaan Strategi Pengembangan Restoran Menggunakan Analisis Swot Dan Metode Qspm (Quantitative Strategic Planning Matriks) (Studi Kasus Restoran Big Burger Malang)

Strategi Pengembangan Sumber Daya Manusia Guna Meningkatkan Kinerja Karyawan Melalui Analisis Swot Divisi Cash Processing Center (Studi Kasus Pada Pt Advantage Scm Kota Semarang)

Ujang Syahrul M. (2016). Analisis Quantitative Strategic Planning Matrix (Qspm) Untuk Menentukan Strategi Bisnis Di Ud. Kontomulyo Badas-Kediri

Strategi Pengembangan Sumber Daya Manusia Guna Meningkatkan Kinerja Karyawan Melalui Analisis Swot Divisi Cash Processing Center (Studi Kasus Pada Pt Advantage Scm Kota Semarang)

Ujang Syahrul M. (2016). Analisis Quantitative Strategic Planning Matrix (Qspm) Untuk Menentukan Strategi Bisnis Di Ud. Kontomulyo Badas-Kediri.

SriRahayu, Djamaludin Malik, S.pd,Msi, Maria M Minarsih, SE,MM. (2019). 